\title{
The expansion of sociocultural theory-oriented mathematical learning model
}

I Made Ardana ${ }^{a^{*}}$, Department of Mathematics Education, Universitas Pendidikan Ganesha, Jalan Udayana No.11, Singaraja 81119, Indonesia, https://orcid.org/0000-0002-0629-8704

I Putu Wisna Ariawan ${ }^{b}$, Department of Mathematics Education, Universitas Pendidikan Ganesha, Jalan Udayana No.11, Singaraja 81119, Indonesia, https://orcid.org/0000-0002-2996-6648

Gusti Ayu Dessy Sugiharni ${ }^{c}$, Department of Information System, Institut Teknologi dan Bisnis STIKOM Bali, Jl. Raya Puputan No.86, Denpasar 80234, Indonesia,https://orcid.org/0000-0003-2578-0456

\section{Suggested Citation:}

Ardana, I. M., Ariawan, I. P. W., Sugiharni, G. A. D. (2021). The expansion of Sociocultural Theory-oriented Mathematical Learning Model. Cypriot Journal of Educational Science. 16(6), 3016-3032. https://doi.org/10.18844/cjes.v16i6.6493

Received from Auguest 15, 2021; revised from October 09, 2021; accepted from December 02, 2021.

${ }^{\circ} 2021$ Birlesik Dunya Yenilik Arastirma ve Yayincilik Merkezi. All rights reserved

\begin{abstract}
The research aim was to obtain a Sociocultural Theory-oriented Mathematics Learning Model with Tri Hita Karana insight that is valid, practical, and effective in developing the good character of students in learning mathematics. This research was a research and development with reference to the development of Plomp. The data collection techniques used tests and questionnaires. The results showed that: (1) the Sociocultural Theory-oriented Mathematics Learning Model with Tri Hita Karana insight is valid, practical, and effective to use to develop the good character of students; (2) there was an increase in the good character of students from the category 'sometimes shows good behavior according to the Tri Hita Karana aspect and often behaves not in accordance with the Tri Hita Karana aspect' to the category 'often and consistently shows good behavior according to the Tri Hita Karana aspect'; and (3) positive student responses to learning.
\end{abstract}

Keywords: Mathematical learning, sociocultural theory, tri hita karana, pawongan, tri pramana

\footnotetext{
"ADDRESS FOR CORRESPONDENCE: I Made Ardana,Universitas Pendidikan Ganesha, Udayana Street No.11 Singaraja-Bali, 81116 ,Indonesia

E-mail address: ardanaimade@undiksha.ac.id / Tel.: +62 857-9234-5155
} 


\section{Introduction}

There are two main goals of education, namely: first to help students master certain knowledge to be bright and smart, then second to help students to be kind and wise (Ardana et al., 2017; Ndiung et al., 2019). The second educational goal is very difficult to achieve so it is very natural to say that moral problems are serious problems that accompany the lives of students wherever and whenever (Berghaus, 2016; Chan, 2020). In connection with that, it is very natural that character education is placed as the basis for realising the vision of national development, namely realising a society with noble, moral, ethical, cultured and civilised morals based on the philosophy of Pancasila (Abdulkarim et al., 2020; Agussalim et al., 2021; Pardo, 2020). Character problems can arise as a result of the inability of students to achieve the first goal of educational goals(Suartama et al., 2020). As a result, students will make all efforts that tend to be negative to achieve good learning outcomes such as: cheating habits, looking for leaked answers from unclear sources, and plagiarism (Davis-Becker, 2013; Kim, 2020; Rhames, 2019). Behaviour that violates ethics, morals, and laws that are mild to severe is still often shown by students at both the primary and higher education levels (Ambang et al., 2019; McCormick et al., 2018; McGowan \& Buttrick, 2017). If this condition is allowed to drag on, then character construction and development based on national culture will never happen. Even the character of students will worsen so that students will never be able to behave and act based on the values that have become their nation personality. In connection with the above problems, the Indonesian government launched NAWACITA where students as strategic and potential agents in building a nation with dignity and character (Pranoto \& Hong, 2020; Sukmayadi \& Yahya, 2020). Students as agents of development must be equipped with character values that are tough, critical, responsible, hardworking, honest, and other characters that provide them with the provisions and competencies to be able to compete both nationally and internationally (Bredemeier \& Shields, 2019; Murray \& Cousens, 2020). This is in line with the concept of general education in Indonesia related to UU No. 20 of 2003 concerning the national education system which highly emphasises the importance of inculcating divine and human values in an integrated manner (Raihani, 2018; Susilana \& Asra, 2013).

In the application of mathematics learning, character education is often slightly neglected (Little, 2019). This is because the teachers are pursuing the cognitive domain of students to achieve the target score of learning (Kazu \& Is, 2018). This target score is called the Minimum Completeness Criteria in the education of Indonesia (Sugiarto \& Sumarsono, 2014). So that it causes a decrease in the moral quality of students when participating in mathematics learning (Martins \& Justi, 2019). Based on this, it is necessary to instill noble values in students when learning mathematics, in addition to invest mathematical concepts. This is in line with the results of several previous studies, namely Mottet's (2015) research which showed that in learning mathematics apart from the cognitive domain, the affective domain also needs to be considered. Alade's (2018) research stated that character education must be inserted into various subjects, especially in the fields of mathematics, science and technology so that selfishness between individuals can be suppressed. Furthermore, the Can and Can's (2020) research showed the assessment of students' character could affect their ability to understand mathematical concepts. Sellbjer's (2018) research stated that students who have positive moral qualities have more math problem solving than students who have negative moral qualities. The 
part of the noble values that need to be integrated into learning mathematics is Tri Hita Karana. Tri Hita Karana is a local wisdom in one of the regions in Indonesia, namely Bali. Tri Hita Karana is a Balinese local wisdom that is used to achieve a balance of life. Tri Hita Karana consists of the following elements: (1) Parahyangan (human relationship with God with the values: Religiosity, Fostering faith, Growing rastiti (piety) in the God, a clean attitude of spiritual physical life); (2) Pawongan (human to human relationship with the values: mutual cooperation, mutual service, effective communication, collaboration, responsibility, learning culture, democracy, discipline, and mutual respect); and (3) Palemahan (human relations with the environment with values: environmental care and preservation) (Divayana et al., 2018).

The inculcation of character values based on national culture through mathematics learning must certainly be done without neglecting the teaching principles and learning principles in mathematics; the characteristics of obtaining mathematical knowledge; and Vigotsky's sociocultural theory, namely students can study in Zone Proximal Development (ZPD) (Eun, 2019; Walle et al., 2013). In order to the benefits of learning in ZPD can be achieved maximally, the integration of the Pawongan section at Tri Hita Karana becomes an important role in learning mathematics. At the Pawongan section, there are several aspects related to Tri Pramana, namely bayu (ability to act), sabda (ability to communicate) and idep (ability to think) (Astuti \& Kasiyan, 2018). The use of students' idep makes they are able to stimulate their thinking and be motivated to have various forms of learning experiences. Then by using the students' sabda makes they are able to carry out collaborations in social interactions so as to allow new learning experiences to occur. Furthermore, the use of bayu which is owned by students makes they are able to summarise all the creativity and thinking power gained from their learning experience to solve a math problem. In connection with the above, it was deemed necessary to conduct research related Development of the Sociocultural Theory-oriented Mathematics Learning Model with Tri Hita Karana insight to Improve Students' Character in Mathematics Learning. This research can contribute to improvements from several previous studies, namely: Godfrey and Mtebe' (2018) research which discussed the negative nature of students in mathematic learning; Research by Henrich et al. (2016) discussed the intervention of students' negative attitudes in mathematics learning; and the research of Sulistyaningsih et al. (2019) where the focus on responsibility for individual assignments makes students lacking in collaborative learning experiences. The purpose of this research was to obtain a Sociocultural Theory-oriented Mathematics Learning Model with Tri Hita Karana insight that is valid, practical, and effective in developing the good character of students in learning mathematics.

\section{Method}

This type of research was development research, because this research focused on developing a model and learning device. The development of this research refers to the Plomp development model (Setyaningsih et al., 2019), whose development includes several phases such as:

\section{(1) The initial investigation phase}

This phase was focused on initial analysis/identification of problems and needs needed in ongoing learning. In addition, the characteristics of mathematics learning according to the 
constructivist view, Tri Hita Karana theory, materials, and characteristics of students were also studied. The results of this study were used as the basis for designing a model which then underlies the design of research instruments.

\section{(2) The design/design phase}

The attention in this phase was focused on the process of formulating/compiling the design model, in the form of an outline of this learning model. In addition, an outline of the theoretical basis of this learning model was also prepared so that an outline of the model was obtained and an instrument design was also made for model development.

\section{(3) Realization/construction phase}

At this stage the Sociocultural Theory-oriented Mathematics Learning Model with Tri Hita Karana insight and its supporting components began to be realised in accordance with the designs that had been designed at the design stage. At this stage, prototype 1 (early/basic draft) of the Sociocultural Theory-oriented Mathematics Learning Model with Tri Hita Karana insight had been produced and its supporting components (validity and practicality test instruments) as a result of the realisation of the design phase.

\section{(4) The test, evaluation \& revision phase}

The prototype obtained in the previous phase was ready to be tested and implemented in a wider scope, then evaluated and revised. The trial focuses on the validity, practicality, and effectiveness of the model.

\section{(5) The implementation phase}

This phase was concerned with implementing the model obtained based on the results of previous trials into a wider scope. This was done through implementation and dissemination aimed at evaluating the practicality and effectiveness of the Sociocultural Theory-oriented Mathematics Learning Model with Tri Hita Karana insight product in a wider scope and gaining the trust of education experts and stakeholders.

The research subjects were elementary school grade 5 students in Singaraja who had registered with the Buleleng District Education and Culture Office. In order for this research to have continuity with the research that was carried out previously in 2020, subjects from $S D$ Negeri 1 Baktisraga Singaraja were involved, namely 28 people from 5 A class and 34 people from $5 B$ class.

The data collection techniques used were: tests for data collection on student learning outcomes scores; a questionnaire to collect data about the character of students; questionnaire to obtain student activity data and student responses to the model; as well as a diary to record things that cannot be recorded through the data collection tools that had been prepared. The instruments of tests and questionnaires used in this study had been tested for validity and reliability using the Pearson-product moment correlation formula to determine validity, and the Cronbach Alpha formula to determine reliability. 
The accuracy of the model was seen from: the activities of students following learning; the improvement/appearance of the students' good character (honesty, discipline, responsibility, tolerance, mutual cooperation, polite, self-confidence); student learning outcomes; and students' responses to the model. Data about the activities of students that were collected based on observations were analysed descriptively. The results of the analysis were then compared with the existing criteria. The classification of students' mathematics learning activity criteria can be seen in Table 1 (Ariawan et al., 2018; Divayana et al., 2021; Mahayukti et al., 2018; Sugiharni et al., 2018)

Table 1. Mathematics learning activities criteria

\begin{tabular}{cll}
\hline No. & \multicolumn{1}{c}{ Score range } & \multicolumn{1}{c}{ Criteria } \\
\hline 1. & Score $\geq 85 \%$ & Very high \\
2. & $70 \% \leq$ Score $<85 \%$ & High \\
3. & $55 \% \leq$ Score $<70 \%$ & Enough \\
4. & $40 \% \leq$ Score $<55 \%$ & Low \\
5. & Score $<40 \%$ & Very low \\
\hline
\end{tabular}

After obtaining the category of student activity criteria in mathematics learning, it was then compared with the criteria for the effectiveness of the model. One aspect of the effectiveness of the model was the appearance/enhancement of the students' character which were collected from a questionnaire and analysed descriptively. Meanwhile, the data about students' responses that collected through questionnaires were analysed descriptively too, namely the percentage calculation of students who gave positive responses. Furthermore, the percentage of positive responses from students was compared with the existing criteria. The model was said to be effective, if it meets the following criteria: 1 ) The activities of students in learning participating were classified as high; 2) The appearance of students' good character was at least in the category of 'often and consistently showing good behavior according to the Tri Hita Karana aspect'; 3) At least $85 \%$ of students had a positive response.

\subsection{Sociocultural Theory-oriented Mathematics Learning Model with Tri Hita Karana insight components}

The Sociocultural Theory-oriented Mathematics Learning Model with Tri Hita Karana insight component to improve the character of students was conveyed by linking the components of the Joyce model (Cheek et al., 2019) with character values that can be built and developed through a Sociocultural theory-oriented Mathematics Learning Model with Tri Hita Karana insight. The Sociocultural Theory-oriented Mathematics Learning Model with Tri Hita Karana insight syntax is as follows.

\section{(1) Preliminary activities}

a. Greeting (insertion of Pawongan values in the sabda aspect).

b. Organising the cleanliness of the environment before starting learning (insertion of Pawongan values in the bayu aspect and insertion of Palemahan values).

c. Presence (insertion of the Pawong value in the bayu aspect). 
d. Prayers together according to their respective beliefs (insertion of the Pawongan value in the Idep aspect and the insertion of the Parahyangan value).

e. Apperception

The learning process begins by the teacher by facilitating students to make a connection between the learning tasks that were being handled by students and their past experiences related to academics, personal, and culture. This means that the idep aspect in the pawongan value orientation was used for reasoning. The aim was to involve students in learning by arousing their curiosity, drawing their attention to the problems at hand, or the sabda aspect of the pawongan value orientation was used to ask some questions that make them think. In addition, this stage provided opportunities for teachers and students through evaluation activities to identify the initial concepts which they have were relating to the new concepts being studied (Kartal \& Kici, 2020). It was by considering whether the initial concept is appropriate or incorrect (misconception). It was at this stage that the teacher identified the strengths and weaknesses of each individual or group because learning was carried out in ZPD. This was intended so that teachers make it easier to adjust the learning carried out with the learning experiences that each individual or group has against the knowledge learned (Diken, 2020). Thus, learning mathematics can be interesting and challenging for students.

It is known that the level of actual development is also called the independent level because students have been able to master skills and can do it independently. Conversely, if it is learned far above the level of potential development, the learning will be ineffective because the level of potential development refers to what students are unable to do independently (Winthrop \& McGivney, 2017). However, by using the bayu aspect of the pawongan value orientation, they will be able to master skills under the guidance of adults or collaborate with more competent colleagues. In this first stage, character values based on national culture are possible to be realised were: curiosity, independence, hard work, and responsibility.

\section{(2) Core activities}

a. Formation of study groups (4-5 members) (insertion of Pawongan values on the bayu aspect).

b. Investigating and discussing mathematical problems related to daily life problems of students with insight into Tri Hita Karana values in cooperative groups (insertion of Pawongan values in the bayu aspect; insertion of Palemahan values; and insertion of Parahyangan values).

c. Utilisation of scaffolding as a way for teachers to help students who have problems (insertion of Pawongan values in the idep aspect).

d. Presentations then questions and answers between group members with tutoring from the teacher (insertion of Pawongan values on aspects of bayu, sabda and idep; insertion of Palemahan values).

In the second stage, learning was carried out by grouping students into cooperative groups of 4-5 members with various abilities and genders. At this stage, the teacher provided math problems that will be solved by students with a level of difficulty between the level of actual and the level of potential. In other words, students were learned in ZPD by using the idep aspect from the Pawongan value orientation. At this stage, the teacher facilitated students when they 
were investigating a mathematical task that was being worked on. By using the bayu aspect from the Pawongan value orientation, so students worked on a task to understand certain concepts, then they acquired problem-solving skills and numeracy skills. When students investigated new material, the initial knowledge that was explored in stage 1 really helps the teacher adjust their learning to the learning experience of students. In order for this to run optimally, the teacher must give challenging assignments. It is the assignments that make sense, stimulate thinking, and can motivate students. In addition, teachers must design meaningful learning and be able to involve all students in social interactions in order to provide opportunities for students. It is to construct new knowledge, as well as provide feedback (evaluation) that helps and encourages further development of students' knowledge according to the speed of their abilities (Lewis, 2018). If the preconception was appropriate, then the teacher directs students and guides students to organise information that supports their ideas towards the conclusions that should be done. If there is a deadlock in students while carrying out an investigation, the teacher must facilitate them in the form of providing scaffolding assistance (Seo, 2019). Character values based on a national culture that can be accommodated in this case by paying attention to cooperative groups, ZPD, Scaffolding, and mathematical-problems with Tri Hita Karana value insights are: tolerance, honesty, hard work, discipline, creativity, independence, democratic, self-confidence, curiosity, mutual respect, communicative, caring for others, responsibility, like helping/mutual cooperation, enthusiasm, leadership, mutual trust and gratitude.

\section{(3) Closing activities}

a. The conclusion by students with teacher assistance (insertion of Pawongan values on the sabda aspect).

b. Giving assignments as a material to deepen the material being studied (insertion of the Pawongan value in the idep aspect).

c. Prayer together as a form of gratitude (insertion of Parahyangan values)

The activity in the third stage involved more than just reviewing what had been learned. During this stage, teachers engaged students in challenging discussions and can broaden their understanding of concepts and problem-solving skills (Johnson, 2017). This was done by using the sabda aspect of the Pawongan value orientation. At this stage, at least character values based on national culture can be accommodated, which include: communication and responsibility.

\section{(4) Evaluation activities}

The evaluation listed in the middle of each learning stage means that at each stage it is necessary to hold an evaluation as part of reflecting on each stage that is passed(Divayana et al., 2021; Alghamdi, 2017). At each stage from the beginning to the end, the teacher assesses the progress of students and asks students to evaluate themselves.

\subsection{Social system}

The Sociocultural Theory-oriented Mathematics Learning Model with Tri Hita Karana insight places students at the center of learning and highly upholds social life in intellectual terms. Thus, 
the cultivation of good habits can be done through the application of the Sociocultural Theoryoriented Mathematics Learning Model with Tri Hita Karana insight so that students are able to behave and act in accordance with the norms prevailing in society.

\subsection{Reaction principles}

The principle of reaction tells how the teacher acts on students and how students respond to the assignment that given by the teacher. In the preliminary stage, the teacher tries to dig up the students' initial knowledge and links the students' initial knowledge with the material/concept being studied. It was as previously mentioned, the teacher positions himself as a mediator and facilitator in learning, so that assistance in the form of scaffolding to students will be carried out if it is deemed necessary. The teacher provides reinforcement to students who have shown significant progress both in terms of knowledge, skills, and attitudes of students. Conversely, if students have not shown significant progress, the teacher provides reinforcement in the right direction. The reactions given by the teacher contribute positively to the knowledge construction process in student learning. The response given by the teacher really depends on the stimulus shown by the students. The principles of reaction of the Sociocultural Theoryoriented Mathematics Learning Model with Tri Hita Karana insight are reflected in the following forms: honesty, sincerity, and other relevant Tri Hita Karana values.

\subsection{Support system}

The support system referred to in this case is what supporting conditions are needed so that the Sociocultural Theory-oriented Mathematics Learning Model with Tri Hita Karana insight can still be implemented properly and effectively. In order for the model to run according to plan, it needs: teachers' understanding of the concept of the Sociocultural Theory-oriented Mathematics Learning Model with Tri Hita Karana insight; teacher mastery in the values of Tri Hita Karana philosophy; teacher skills in implementing the Sociocultural Theory-oriented Mathematics Learning Model with Tri Hita Karana insight; and contextual problems that contain Tri Hita Karana values.

\subsection{Companion impact and instructional impact}

There are two impacts that occur in the application of the learning model, namely the instructional impact and the accompanying impact. The instructional impact of applying the Sociocultural Theory-oriented Mathematics Learning Model with Tri Hita Karana insight is that it makes it easier for students to master the concepts related to the material being studied according to the indicators that must be achieved. While the accompanying impact of this model is the formation of good character in students that reflects the values of the Tri Hita Karana philosophy. It is, there is harmony in the relationship with God (faith, caution, gratitude, discipline), with others (caring for others, tolerance, solidarity, courtesy, honesty), and with the environment (caring for the environment, respecting nature). 


\section{Results}

Student activities in participating in learning by applying the Sociocultural Theory-oriented Mathematics Learning Model with Tri Hita Karana insight can be reported that out of a total of 62 students, most of the students answered 'Yes' to every question asked related to student learning activities. By comparing the overall 'Yes' answers from students with the maximum total of 'Yes' answers, it was obtained that an average of 95.2\% of students answered 'Yes' questions related to student activities. This showed that the activities of students in learning participating with the Sociocultural Theory-oriented Mathematics Learning Model with Tri Hita Karana insight were in the very high category. The appearance of good characters in students during learning by applying the Sociocultural Theory-oriented Mathematics Learning Model with Tri Hita Karana insight can be reported as shown in Tables 2 and 3.

Table 2. Development of the 5A grade students' good character

\begin{tabular}{llrrrrrc}
\hline No. & Character & Meet-1 & Meet-2 & Meet-3 & Meet-4 & Meet-5 & Meet-6 \\
\hline 1 & Honesty & 2.3 & 2.7 & 3.0 & 3.0 & 3.0 & 3.0 \\
2 & Discipline & 2.2 & 2.4 & 3.0 & 3.0 & 3.0 & 3.0 \\
3 & Responsible & 2.4 & 2.4 & 2.6 & 2.6 & 2.7 & 2.6 \\
4 & Tolerance & 2.2 & 2.5 & 2.5 & 2.5 & 2.6 & 2.6 \\
5 & Mutual cooperation & 2.2 & 2.5 & 2.5 & 2.5 & 2.6 & 2.6 \\
6 & Polite & 2.3 & 2.6 & 2.6 & 2.8 & 2.8 & 2.8 \\
7 & Confidence & 2.2 & 2.2 & 2.3 & 2.3 & 2.4 & 2.6 \\
\hline
\end{tabular}

Table 3. Development of the 5B grade students' good character

\begin{tabular}{llcccccc}
\hline No. & \multicolumn{1}{c}{ Character } & Meet-1 & Meet-2 & Meet-3 & Meet-4 & Meet-5 & Meet-6 \\
\hline 1 & Honesty & 2.3 & 2.6 & 2.9 & 3.0 & 3.2 & 3.3 \\
2 & Discipline & 2.3 & 2.5 & 2.9 & 3.1 & 3.2 & 3.3 \\
3 & Responsible & 2.6 & 2.8 & 3.0 & 3.1 & 3.2 & 3.2 \\
4 & Tolerance & 2.3 & 2.4 & 2.6 & 2.9 & 3.2 & 3.3 \\
5 & Mutual cooperation & 2.5 & 2.6 & 2.6 & 2.9 & 3.1 & 3.3 \\
6 & Polite & 2.6 & 2.6 & 2.7 & 2.7 & 2.9 & 3.1 \\
7 & Confidence & 2.5 & 2.5 & 2.6 & 2.6 & 2.9 & 3.1 \\
\hline
\end{tabular}

Tables 2 and 3 show that all the good characters of students (honesty, discipline, responsibility, tolerance, mutual cooperation, courtesy and self-confidence) in the initial condition were in the category 'sometimes showing good behavior according to Tri Hita Karana aspects and often behaving not according to the Tri Hita Karana aspect'. However, in 5A class and $5 \mathrm{~B}$ class, it can be seen that starting at meeting 1 there has been a slight improvement in the character of students. If we pay attention to the good character scores from meeting 1 to the next meeting, there tends to be a change for the better. So that the good character scores of students at the sixth meeting (last) were all close to score 3. It showed that the good character scores of students tend to be in the category of 'often and consistently showing good behavior according to the Tri Hita Karana aspect'. This showed that changes in the good character scores of students occur very significantly when compared with the good character scores in the initial conditions. This showed that the Sociocultural Theory-oriented Mathematics Learning Model with Tri Hita Karana insight is very suitable to be used to improve the students' good character. 
Furthermore, the students' learning outcomes on the implementation of the Sociocultural Theory-oriented Mathematics Learning Model with Tri Hita Karana insight are given in Table 4.

Table 4. Student learning outcomes recapitulation

\begin{tabular}{lllccc}
\hline \multirow{2}{*}{ No } & \multirow{2}{*}{ Learning outcomes } & \multicolumn{4}{c}{ Class } \\
\cline { 3 - 6 } & & \multicolumn{3}{c}{$5 \mathrm{~A}$} & \multicolumn{3}{c}{$5 \mathrm{~B}$} \\
\cline { 3 - 6 } & & Before & After & Before & After \\
\hline 1 & Average & 55.2 & 73.0 & 55.3 & 85 \\
2 & Absorption & $46.2 \%$ & $73.5 \%$ & $55.3 \%$ & $85 \%$ \\
3 & Mastery learning & $100 \%$ & $100 \%$ & $100 \%$ & $100 \%$ \\
\hline & Curriculum target & $10.4 \%$ & $40.6 \%$ & $100 \%$ \\
\hline
\end{tabular}

Table 4 shows that there was a very significant change in student learning outcomes before and after the implementation of the Sociocultural Theory-oriented Mathematics Learning Model with Tri Hita Karana insight. This can be seen that at the time before the application of the Sociocultural Theory-oriented Mathematics Learning Model with Tri Hita Karana insight the average learning outcomes of students only reached the passing limit. But after the application of the Sociocultural Theory-oriented Mathematics Learning Model with Tri Hita Karana insight, there was a significant increase so that it reached the good category. Meanwhile, students' learning completeness after applying the Sociocultural Theory-oriented Mathematics Learning Model with Tri Hita Karana insight was very high. It was in $5 \mathrm{~A}$ class at $96.4 \%$ and in $5 \mathrm{~B}$ class at $100 \%$. The results of a questionnaire about students' responses to the implementation of the learning process using the Sociocultural Theory-oriented Mathematics Learning Model with Tri Hita Karana insight showed that of the 10 statements submitted there were several statements that were given negative responses by some students. Although it was like those, because students who gave positive responses were $91.9 \%$ which exceeded $85 \%$, it can be concluded that the overall responses of students to the Sociocultural Theory-oriented Mathematics Learning Model with Tri Hita Karana insight were positive. Because the activities of students were in the category of 'very high activeness', the appearance of students' good character was in the category of 'often and consistently showing good behavior according to the Tri Hita Karana aspect'. The learning outcomes of students were in a good category, and the students' responses to the implementation of the Sociocultural Theory-oriented Mathematics Learning Model with Tri Hita Karana insight were in the 'positive' category, so it can be concluded that the Sociocultural Theory-oriented Mathematics Learning Model with Tri Hita Karana insight is effective.

\section{Discussions}

The results showed that the Sociocultural Theory-oriented Mathematics Learning Model with Tri Hita Karana insight met the criteria of validity, practicality, and effectiveness. The syntax for the Sociocultural Theory-oriented Mathematics Learning Model with Tri Hita Karana insight consists of four phases, namely the Preliminary, Core, Closing (taking conclusions), and Evaluation phases, as can be seen fully in Figure 1. 


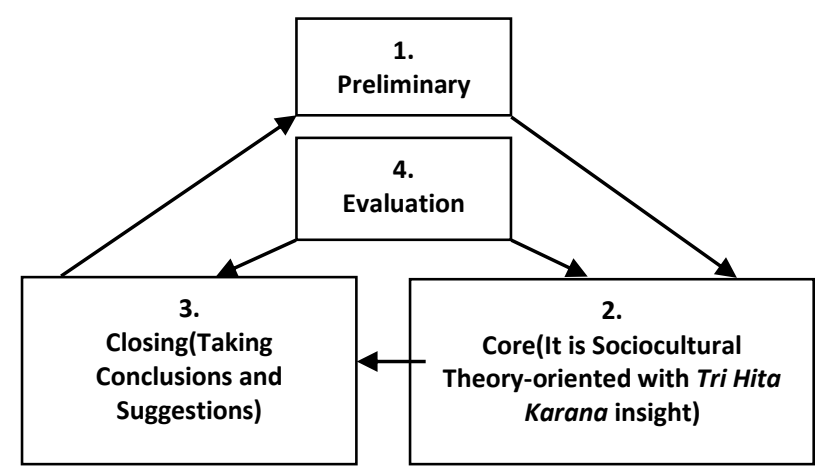

Figure 1. Syntax of Sociocultural Theory-oriented Mathematics Learning Model with Tri Hita Karana insight

The preliminary stage in the Sociocultural Theory-oriented Mathematics Learning Model with Tri Hita Karana insight is carried out as the beginning to strengthen the students' good character through several activities such as: Say the opening greetings (insertion of Pawongan values on the sabda aspect); Arranging the cleanliness of the learning environment before starting learning (insertion of Palemahan values and insertion of Pawongan values on the bayu aspect); Obedience and discipline in presence (insertion of Pawongan values on the bayu aspect); Prayer together according to their respective beliefs (insertion of Parahyangan values); and apperception. Apperception activities are carried out with the aim of making it easier for students to understand the concepts they are going to learn. In other words, it is to make assimilation or accommodation easy for students through students' reflective thinking. This is done in accordance with the opinion of Fosnot which stated that through reflective thinking a person will get new information/ideas by connecting information that is already owned or modifying the ideas/information that is already owned (Haynor, 2018). Assimilation occurs when a new concept 'fit' with previous knowledge and new information expands existing networks. Accommodation occurs when a new concept does not 'fit' with the existing network (causing what Piaget called disequilibrium), so that the brain can change or replace existing schemes (Kural \& Kocakulah, 2016). The task of the teacher in this case is to examine whether or not the students' ideas match the new information to be learned. This is where the preliminary-stage relationship with the evaluation in Figure 1. If the information that students have is appropriate, it means that learning can continue to the Core stage. Vice versa, if it is not appropriate, the teacher will guide students to adjust their knowledge with the new information to be learned.

At the Core stage, students are taught in cooperative groups consisting of 4-5 members with various genders and academic abilities. It is at this core activity that good character can be optimally enhanced. The good character 'honest' can be increased considering that some of the indicators are observed to change significantly, such as: students try to convey something in accordance with the actual situation; willing and brave to admit their mistakes, shortcomings or limitations; do not like to cheat or do not violate activities when they doing independent activities; not lying (students express their opinions as they are); and not manipulating facts/information (especially when asked to correct one's own work). This is due to the habituation in the Sociocultural Theory-oriented Mathematics Learning Model with Tri Hita Karana insight in the form of problem discussion. So that students are trained to understand their responsibilities towards themselves and their responsibilities to the group. This habit is 
carried out starting from the teacher who gives an example of honesty, such as recognising weaknesses when there is something that cannot be explained. This can happen because the teacher first embraces the values contained in Tri Hita Karana which are ready to be implemented in learning. It is done before learning with the Sociocultural Theory-oriented Mathematics Learning Model with Tri Hita Karana insight is carried out. This is in accordance with the results of research conducted by Hermino and Arifin (2020), namely if a teacher wants to build an honest character in their students, then that honest character must be accustomed to appearing in the teacher. Furthermore, this is also in accordance with the research of Halonen et al. (2020)and Suastika et al. (2021)that each indicator of character education is indicated by strategies and learning methods that reflect the value of each character. The learning method in question can be in the form of assignments, learning practices, and habituation so that character education values can be implemented.

The improvement of the good character of 'discipline' occurs due to the appearance consistency of several indicators, such as: arrival on time and not skipping class; complete the task according to the set time; remind each other group/class members so that all group/class assignments are carried out properly; remind each other in order to maintain class order or so that the class does not make a fuss; orderly and comply with all rules and regulations that apply, especially when studying. The habituation carried out in this case is to be an example. It is coming on time; what the teacher says in accordance with the action; and convey the benefits of self-discipline both now and in any situation. This is in accordance with what Afshar and Hamzavi (2017) said, that is a person will have a balanced lifestyle if in his/her life he/she is always disciplined and on time in carrying out something. By discipline, a person will find it easier to understand something which he/she is learning, and life will be organised according to the disciplinary schedule that has been made. The increase in the 'responsibility' good character occurs because of the indicators appearance consistency such as: students' efforts to carry out tasks with good quality results, both individual and group assignments; doing assignments based on their own work; ready to accept the risk of the actions carried out; apologise to friends when they make mistakes; and are responsible for every learning action that is carried out.

The increase in the 'tolerance' good character occurs because of the indicators appearance consistency such as: care about the environment, especially seen when caring for group members who do not understand the concept; respect to the ability lack of friends/group members; respect to differences of opinion that occur; open trait; does not disturb friends who are working; does not impose an opinion; willing to cooperate with anyone; not prioritising personal interests; and the comfort of students in discussing in groups. The improvement in the good character of 'mutual cooperation' occurs due to the consistency of the indicators appearance such as: actively involved in completing group assignments; willing to carry out tasks according to mutual agreement; encourage other friends to work together to achieve common goals; and are willing to help other friends unconditionally or without much reason. This is able to arise as a result of habituation in the application of cooperative learning. This is in accordance with Leopold and Smith (2020) who said that the focus of values and skills that are targeted in collaborative learning strategies is the ability to work together. The increase in good character 'polite' occurs because of the indicators appearance consistency such as: teacher and students do not using profanity during the lesson; do not interrupt the speaker at the right time; express thanks after being assisted; and treat others as her/his self. The increase in good character 'self- 
confidence' occurs because of the indicators appearance consistency such as: opine without showing any doubt; not easily discouraged; dare to ask, opine, or answer questions; and not awkward in acting. This confident character is accustomed to appearing in training students to communicate in the discussion of any problems that must be solved.

In this connection, Gray (2018) said that the focus of character strengthening in the discussion strategy is the ability to think critically, the ability to communicate, respect other people's opinions, be confident, and influence others through good argumentation procedures. Learning activities at the conclusion-taking stage are more than just asking for confirmation and conclusions from students. In this stage, the teacher engages students in activities and discussions that challenge and broaden their understanding of concepts and problem-solving skills. Learners apply what they have learned about math assignments and some of their experiences to develop, expand, connect, and deepen their understanding of concepts. Some of the obstacles found in this study were as follows: (1) there were some mathematical materials that were difficult to present in problems that contain character; (2) it was difficult for the teacher to make character-based math problems; (3) the occurrence of a prolonged debate in the study group, so that the temptation often occurs to the teacher to tell the answer directly; (4) teacher control of the study group had not been carried out properly so that the learning motivation of some people decreases as a result of the group's results which were not right or even wrong; and (5) there were some students who were less active in their study groups.

\section{Conclusion and recommendations}

Based on the results of the research, discussion, and findings that had been stated previously, several things can be concluded as follows:

1) The resulting Sociocultural Theory-oriented Mathematics Learning Model with Tri Hita Karana insight has a syntax consisting of four phases, namely: Phase 1: Introduction, Phase 2: Core (Sociocultural Theory orientation and Tri Hita Karana insight); Phase 3: Drawing Conclusions; Phase 4: Evaluation.

2) The Sociocultural Theory-oriented Mathematics Learning Model with Tri Hita Karana insight met the validity criteria of a model, and also met the criteria for practicality and effectiveness.

3) The Sociocultural Theory-oriented Mathematics Learning Model with Tri Hita Karana insight was very effective in helping students understand the mathematical concepts which were being studied.

Things that will be done in the future to overcome the obstacles experienced in this study are as follows. Constraints (1) and (2) are overcome by ensuring that before applying the Sociocultural Theory-oriented Mathematics Learning Model with Tri Hita Karana insight, a teacher needs to: (a) master the characteristics or components of the Sociocultural Theoryoriented Mathematics Learning Model with Tri Hita Karana insight; (b) understand well the Tri Hita Karana values; (c) do the training to synchronise mathematical material with characters with insight into Tri Hita Karana values. Obstacle (3) is overcome by making a learning agenda or time limit for each activity, for example 35 minutes of group discussion, 25 minutes of class discussion, and 10 minutes of deepening and summarising the material. Constraint (4) is 
overcome by ensuring that each group is well controlled and facilitated so that students can minimise errors in conclusions. Constraint (5) is overcome by maximising peer tutoring and definitively informing students that group achievement is highly dependent on the achievement of each group members.

\section{References}

Abdulkarim, A., Komalasari, K., Saripudin, D., Ratmaningsih, N., \& Anggraini, D. N. (2020). Development of a Unity in Diversity-Based Pancasila Education Text Book for Indonesian Universities. International Journal of Instruction, 13(1), 371-386. https://doi.org/10.29333/iji.2020.13125a

Afshar, H. S., \& Hamzavi, R. (2017). An Investigation into the Characteristics of Iranian EFL Teachers of Senior Secondary Schools and Language Institutes. Iranian Journal of Language Teaching Research, 5(1), 21-36.

Agussalim, A., Widjaja, S. U. M., Haryono, A., \& Wahyono, H. (2021). Pancasila Economic Character Literacy Program for High School Students. International Journal of Instruction, 14(1), 235-252. https://doi.org/10.29333/iji.2021.14114a

Alade, F. (2018). Character Portrayals in STEM-Focused Educational Television Shows and Their Impact on Children's Attitudes towards STEM. Northwestern University.

Alghamdi, M. S. (2017). The Reality and Difficulties of Employing ICT in Teaching from the Perspective of Math Teachers of Middle Stage in Riyadh. International Education Studies, 10(12), 109-129. https://doi.org/10.5539/ies.v10n12p109

Ambang, O. A., Alloggio, S., \& Tandlich, R. (2019). Moral Reciprocity, Ethics of Appropriation of Indigenous Medicinal Plant Knowledge and Associated Biopiracy. Acta Educationis Generalis, 9(2), 24-65. https://doi.org/10.2478/atd-2019-0007

Ardana, I. M., Wisna Ariawan, I. P., \& Hendra Divayana, D. G. (2017). Measuring the Effectiveness of BLCS Model (Bruner, Local Culture, Scaffolding) in Mathematics Teaching by using Expert System-Based CSE-UCLA. International Journal of Education and Management Engineering, 7(4), 1-12. https://doi.org/10.5815/ijeme.2017.04.01

Ariawan, I. P. W., Simatupang, W., Ishak, A. M., Agung, A. A. G., Suratmin, Adiarta, A., \& Divayana, D. G. H. (2018). Development of ANEKA Evaluation Model Based on Topsis in Searching the Dominant Aspects of Computer Learning Quality Determinants. Journal of Theoretical and Applied Information Technology, 96(19), 6580-6596.

Astuti, N. L. P. W., \& Kasiyan. (2018). The Values of Taksu in Pendet Dance at Saraswati Balinese Dance Studio Yogyakarta. Advances in Social Science, Education and Humanities Research, 327, 274-279.

Berghaus, P. T. (2016). The Problems of Authority and the Want of Apprenticeship in Soldiers' Character Development. Journal of Moral Education, 45(3), 324-337. https://doi.org/10.1080/03057240.2016.1204272

Bredemeier, B. L., \& Shields, D. L. (2019). Social Justice, Character Education, and Sport: A Position Statement. Quest, 202-214. https://doi.org/10.1080/00336297.2019.1608270

Can, D., \& Can, V. (2020). Fairness in Resource Distribution: Relationship between Children's Moral Reasoning and Logical Reasoning. Acta Educationis Generalis, 10(3), 66-86. 
Chan, C. W. (2020). Moral Education in Hong Kong Kindergartens: An Analysis of the Preschool Curriculum Guides. Global Studies of Childhood, 10(2), 156-169. https://doi.org/10.1177/2043610619885385

Cheek, A. E., Idol, W. A., Jones, J. L., \& Holden, K. B. (2019). Infusing Technology throughout Teacher Preparation Programs to Support Preservice Teacher Development. Journal of Special Education Apprenticeship, 8(2), 1-14.

Davis-Becker, S. (2013). Construct Maps: Do They Make the Unclear Clear? Measurement: Interdisciplinary Research and Perspectives, 11(4), 174-176. https://doi.org/10.1080/15366367.2013.857980

Diken, E. H. (2020). The Opinions of Science Teachers on the Weaknesses and Strengths of LGS and TEOG Systems (The Case of Kars Province). Journal of Curriculum and Teaching, 9(2), 20-32. https://doi.org/10.5430/jct.v9n2p20

Divayana, D. G. H., Sudirtha, I. G., \& Suartama, I. K. (2021). Digital Test Instruments Based on Wondershare-Superitem for Supporting Distance Learning Implementation of Assessment Course. International Journal of Instruction, 14(4), 945-964. https://doi.org/10.29333/iji.2021.14454a

Divayana, D. G. H., Ariawan, I. P. W., Adiarta, A., Parmiti, D. P., Mahendra, I. W. E., \& Parmithi, N. N. (2018). Development of ANEKA-based countenance model integrated with Tri Hita Karana-SAW in evaluating student's character and quality of computer learning in Bali. Journal of Engineering and Applied Sciences, 13(15), 6303-6315.

Divayana, D. G. H., Suyasa, P. W. A., \& Widiartini, N. K. (2021). An innovative model as evaluation model for information technology-based learning at ICT vocational schools. Heliyon, 7(2). https://doi.org/10.1016/j.heliyon.2021.e06347

Eun, B. (2019). The Zone of Proximal Development as an Overarching Concept: A Framework for Synthesizing Vygotsky's Theories. Educational Philosophy and Theory, 51(1), 18-30.

Gray, K. M. (2018). Characterizing Environmental Health Literacy Related to Fish Consumption Advisories: Knowledge and Beliefs of Informal Educators in a Southeastern State. North Carolina State University.

Halonen, J. S., Nolan, S. A., Frantz, S., Hoss, R. A., McCarthy, M. A., Pusateri, T., \& Wickes, K. (2020). The Challenge of Assessing Character: Measuring APA Goal 3 Student Learning $\begin{array}{llll}\text { Outcomes. Teaching } \quad \text { of 285-295. } & \text { Psychology, }\end{array}$ https://doi.org/10.1177/0098628320945119

Haynor, M. I. (2018). Applying a Constructivist Approach to the Assessment of Compositions in a Secondary Technology-Based Music Classroom. Boston University.

Henrich, A., Sloughter, J. M., Anderson, J., \& Bahuaud, E. (2016). Addressing Negative Math $\begin{array}{llll}\text { Attitudes with } \quad \text { Service-Learning. } & \text { 788-802. }\end{array}$ https://doi.org/10.1080/10511970.2016.1174967

Hermino, A., \& Arifin, I. (2020). Contextual Character Education for Students in the Senior High School. European Journal of Educational Research, 9(3), 1009-1023. https://doi.org/10.12973/eu-jer.9.3.1009

Johnson, N. C. (2017). Expanding Competence: Supporting Students to Engage with Each Other's Mathematical Ideas. University of California, Los Angeles.

Kartal, G., \& Kici, D. (2020). Reflection through Drama and Concept Maps for Preservice Teacher Education in Information Communication Technologies. Education and Information 
Technologies, 25(6), 4861-4881. https://doi.org/10.1007/s10639-020-10194-4

Kazu, I. Y., \& Is, A. (2018). An Investigation about Actualization Levels of Learning Outcomes in Early Childhood Curriculum. Journal of Education and Training Studies, 6(3), 66-77. https://doi.org/10.11114/jets.v6i3.2928

Kim, Y. (2020). Partial Identification of Answer Reviewing Effects in Multiple-Choice Exams. Journal of Educational Measurement, 57(4), 511-526. https://doi.org/10.1111/jedm.12259

Kural, M., \& Kocakulah, M. S. (2016). Teaching for Hot Conceptual Change: Towards a New Model, beyond the Cold and Warm Ones. European Journal of Education Studies, 2(8), 140.

Leopold, H., \& Smith, A. (2020). Implementing Reflective Group Work Activities in a Large Chemistry Lab to Support Collaborative Learning. Education Sciences, 10(7), 1-19.

Little, J. (2019). Connecting Mathematics with Science to Enhance Student Achievement -- A Position Paper (pp. 452-459). Mathematics Education Research Group of Australasia.

Mahayukti, M.A., Dantes, N., Candiasa, I.M., Marhaeni, A.A.I.N., Gita, I.N., \&Divayana, D. G. H. (2018). Computer-based Portfolio Assessment to Enhance Students' Self-Regulated Learning. Journal of Theoretical and Applied Information Technology, 96(8), 2351-2360.

Martins, M., \& Justi, R. (2019). An Instrument for Analysing Students' Argumentative Reasoning When Participating in Debates. International Journal of Science Education, 41(6), 713-738. https://doi.org/10.1080/09500693.2019.1579005

McCormick, Marleen; Buttrick, Hilary; McGowan, R. (2018). Ethics of Entrepreneurship: Should We Be Teaching Students the Inevitable Moral Dilemmas That Challenge All Entrepreneurs? Journal of Learning in Higher Education, 14(1), 29-36.

McGowan, Richard J.; Buttrick, H. G. (2017). Teaching Environmental Ethics: Moral Considerations and Legislative Action. Journal of Learning in Higher Education, 13(1), 4954.

Mottet, T. P. (2015). FORUM: Affective Learning. Affective Learning from a Cognitive Neuroscientific Perspective. Communication Education, 64(4), 508-510. https://doi.org/10.1080/03634523.2015.1064144

Murray, J., \& Cousens, D. (2020). Primary School Children's Beliefs Associating Extra-Curricular Provision with Non-Cognitive Skills and Academic Achievement. Education 3-13, 48(1), 3753. https://doi.org/10.1080/03004279.2019.1572769

Ndiung, S., Dantes, N., Ardana, I., \& Marhaeni, A. (2019). Treffinger Creative Learning Model with RME Principles on Creative Thinking Skill by Considering Numerical Ability. International Journal of Instruction, 12(3), 731-744. https://doi.org/10.29333/iji.2019.12344a

Pardo, N. (2020). Character Development Assessment in Imagine Schools. Journal of Character Education, 16(2), 69-72.

Raihani, R. (2018). Education for Multicultural Citizens in Indonesia: Policies and Practices. Compare: A Journal of Comparative and International Education, 48(6), 992-1009. https://doi.org/10.1080/03057925.2017.1399250

Rees Lewis, D. G. (2018). Beyond Problems on a Platter: Creating Tools for Teaching Planning in Real World Design. Northwestern University.

Rhames, M. A. (2019). The "F-Word" of Social and Emotional Learning: Faith (pp. 1-8). American Enterprise Institute

Sellbjer, S. (2018). 'Have you read my comments? It is not noticeable. Change!' An analysis of 
feedback given to students who have failed examinations. Assessment \& Evaluation in Higher Education, 43(2), 163-174. https://doi.org/10.1080/02602938.2017.1310801

Seo, B.-I. (2019). An Investigation of How 7th Grade and 8th Grade Students Manipulate Mathematical Writing Elements. Perspectives in Education, 37(2), 141-159.

Setyaningsih, N., Rejeki, S., \& Ishartono, N. (2019). Developing Realistic and Child-Friendly Learning Model for Teaching Mathematics. Journal of Research and Advances in Mathematics Education, 4(2), 79-88.

Suartama, I. K., Triwahyuni, E., Sukardi, A., \& Hastuti, W. D. (2020). Development of E-Learning Oriented Inquiry Learning Based on Character Education in Multimedia Course. European Journal of Educational Research, 9(4), 1591-1603. https://doi.org/10.12973/eujer.9.4.1591

Suastika, I. N., Suartama, I. K., Sanjaya, D. B., \& Arta, K. . (2021). Application of multiculturalbased learning model syntax of social studies learning. Cypriot Journal of Educational Sciences, 16(4), 1660-1679. https://doi.org/10.18844/cjes.v16i4.6030

Sugiarto, D., \& Sumarsono, P. (2014). The Implementation of Think-Pair-Share Model to Improve Students' Ability in Reading Narrative Texts. International Journal of English and Education, 3(3), 206-215.

Sugiharni, G. A. D., Setiasih, N. W., Mahendra, I. W. E., Ardana, I. M., \& Divayana, D. G. H. (2018). Development of Alkin Model Instruments as Evaluation Tools of Blended Learning Implementation in Discrete Mathematics Course on STIKOM Bali. Journal of Theoretical and Applied Information Technology, 96(17).

Sugiyo Pranoto, Y. K., \& Hong, J. (2020). The Aspirations of Young Indonesian Children. Global Studies of Childhood, 10(2), 202-209. https://doi.org/10.1177/2043610619869704

Sukmayadi, V., \& Yahya, A. H. (2020). Indonesian Education Landscape and the 21st Century Challenges. Journal of Social Studies Education Research, 11(4), 219-234.

Sulistyaningsih, D., Purnomo, \& Aziz, A. (2019). Development of Learning Design for Mathematics Manipulatives Learning Based on E-Learning and Character Building. International Electronic Journal of Mathematics Education, 14(3), 197-205. https://doi.org/10.29333/iejme/3996

Susilana, R., \& Asra. (2013). Development of Quality Assurance System in Culture and Nation Character Education in Primary Education in Indonesia. Malaysian Online Journal of Educational Sciences, 1(2), 17-24. https://doi.org/https://files.eric.ed.gov/fulltext/EJ1086212.pdf

Walle, John A. Van DeElementary and Middle School Mathematics, T. D., Karp, K. S., \& BayWilliams, J. M. (2013). Elementary and Middle School Mathematics, Teaching Developmentally. Pearson Education, Inc.

Winthrop, R., \& McGivney, E. (2017). Can We Leapfrog? The Potential of Education Innovations to Rapidly Accelerate Progress. Skills for a Changing World. Center for Universal Education at The Brookings Institution. 